\title{
Rhaphidophora korthalsii modulates peripheral blood natural killer cell proliferation, cytokine secretion and cytotoxicity
}

\author{
Swee Keong Yeap ${ }^{1}$, Abdul Rahman Omar ${ }^{1,2}$, Wan Yong Ho ${ }^{3}$, Boon Kee Beh ${ }^{5}$, Abdul Manaf $\mathrm{Ali}^{4}$ \\ and Noorjahan Banu Alitheen ${ }^{3 *}$
}

\begin{abstract}
Background: Rhaphidophora korthalsii (Araceae) is a root-climber plant which has been widely used in Chinese traditional medicine for cancer and skin disease treatment. Previous reports have recorded its immunomodulatory effects on mice splenocyte and human peripheral blood. This study investigated the potential immunostimulatory effect of Rhaphidophora korthalsii on human PBMC enriched NK cell.

Methods: PBMC was exposed to various concentrations of $R$. korthalsii extract and the T and NK cell population in the control and extract treated PBMC were identified by immunophenotyping. Intracellular perforin and granzyme B expressions were detected by flow cytometry and extra-cellular Granzyme B, IFN- $y$ and TNF-a production in the isolated NK cells were determined by ELISA. The cytotoxicity of effector NK cell towards target K562 cell was assessed by CytoTox 96 assay.
\end{abstract}

Results: Rhaphidophora korthalsii methanol extract significantly increased PBMC NK cell population and intracellular perforin and granzyme B expressions. Moreover, the extract also enhanced the secretion of IFN- $\gamma$ and TNF-a which subsequently enhanced the cytotoxicity of NK cell against the NK sensitive target K562 cell line. NK cell enriched with extract treated PBMC showed better activation than NK cell directly treated with the extract.

Conclusion: Our findings indicated a potential IL-2 free immunotherapy through direct and indirect $R$. korthalsii stimulation on NK cell activation.

Keywords: Rhaphidophora korthalsii, NK cell, Immunomodulation

\section{Background}

Immunostimulator is one type of immunomodulator which can strengthen the body's immune system [1]. One of the research directions in complementary medicine is to discover a safer and effective immunostimulators which can help in preventing diseases and to be used in clinical practice for patients with immune disorders. Recent years, the focus on the study of biological activities such as immunostimulatory effect from plant extracts based on ethnopharmacology has been revived all over the world due to the low or absence of toxicity, complete biodegradability,

\footnotetext{
* Correspondence: noorjahan@biotech.upm.edu.my

${ }^{3}$ Department of Cell and Molecular Biology, Faculty of Biotechnology and Biomolecular Sciences, University Putra Malaysia, 43400, Serdang, Selangor, Malaysia

Full list of author information is available at the end of the article
}

availability from renewable resources and low production cost in comparison to pharmaceutical compounds [2-4].

Rhaphidophora korthalsii, Schott. is a traditional herb under the family of Araceae. It can be widely found throughout Asia region such as India, Sri Lanka, Cambodia, Venezuela, Malaysia, Australia and Indonesia [5]. $R$. korthalsii has been traditionally used for cancers and skin diseases treatment. Earlier studies have found that $R$. korthalsii extract possesses selective cytotoxic and antioxidant effects. For example, the extract was found to suppress P388, Molt 4, KB, SW 620 and T-47D cell lines. The antioxidant activity of the extract had subsequently contributed to the enrichment of macrophage cell number [6-8]. On top of that, the extract had also showed to exert immunomodulatory effect on mice splenocyte and human peripheral blood mononuclear cell (PBMC) proliferation, 
increase of the NK cell population, cytokines secretion and cytotoxicity in vitro and in vivo [8-11].

NK cells are believed to play an important role as effector cells to lyse cancerous target when compared to other types of lymphocytes in human immune system. This is because NK cell forms an early immune defense during innate immunity before the emergence of $\mathrm{T}$ and $\mathrm{B}$ lymphocytes upon the entrance of pathogen or formation of tumor [12]. To date, the majority of the studies reported on immunoregulation of $R$. korthalsii were using a mix population of lymphocytes. However, little or no information is available on the modulation of $R$. korthalsii against targeted lymphocyte population especially the effects on NK cell. To address this question, this study was carried out to present the immunoregulatory effect of $R$. korthalsii on human PBMC NK cell activation and cytotoxicity.

\section{Methods}

\section{Reagents and chemicals}

Fluoroisothiocyanate (FITC)- labeled CD16, CD3, perforin, granzyme $\mathrm{B}$, and phycoerytherin (PE)-labeled CD56 and IL-2 neutralizing MQ1-17H12 monoclonal antibodies, GolgiStop $^{\text {twi }}$ solution and Perm/Wash ${ }^{\text {twi }}$ solution were purchased from BD, USA; isotype control mouse IgG1 and FITC goat anti-rabbit Ig were purchased from Abcam, USA; Enzyme Link Immunosorbent Assay (ELISA) kit for IFN- $\gamma$, TNF- $\alpha$ and Granzyme B cytokines from Bender MedSystems, Austria; NK cell and T cell isolation kits from Milteny Biotech, Germany; human recombinant human Interleukin 2 (rhIL-2), trypan blue solution, DMEM were brought from Sigma, USA.

\section{Preparation of the methanol extract of $R$. korthalsii}

$R$. korthalsii methanol extract was prepared using the same extraction method as stated in our earlier study [9]. $R$. korthalsii leaves (voucher no: FRIM 33687) were collected from Georgetown Herbal Farm, Penang, Malaysia and was authenticated by Mr. Lim Chung Lu from the Forestry Division of the Forest Research Institute of Malaysia (Kepong, Selangor). The leaves were then air-dried and extracted using $250 \mathrm{~mL}$ of methanol (J.T. Baker, USA) for 72 hours. The extract was filtered with Whatman filter paper no 1 and evaporated to dryness under reduced pressure using Aspirator A-3S (EYELA, Japan) at $<40^{\circ} \mathrm{C}$. This process was repeated three times (yield 27.3\%,w/w) respectively. The methanol extract was dissolved in DMSO (Sigma, USA) at a concentration of $10 \mathrm{mg} / \mathrm{mL}$.

\section{Cell line and cell preparation}

PBMC was isolated from five different blood donors using Ficoll-Plaque Plus (Amersham Biosciences, USA) according to the manufacturer's protocol. Informed consent was acquired from all donors and this work was carried out in compliance with the Helsinki Declaration for ethical approaches of conducting scientific research. This study was approved by the ethical committee of University Putra Malaysia. In brief, one ratio of diluted blood (1:1 ratio in PBS) sample was layered on 2 ratio of Ficoll-Plaque Plus (Amersham Biosciences, USA), pelleted (400 $g$, 40 minutes at $18-20^{\circ} \mathrm{C}$ ) and the buffy coat was collected, washed twice with PBS and cultured in DMEM (Sigma, USA) $(100 \mathrm{IU} / \mathrm{mL}$ of penicillin, $100 \mu \mathrm{g} / \mathrm{mL}$ of streptomycin [Flowlab, Australia] and $10 \% \mathrm{v} / \mathrm{v}$ Fetal Bovine Serum [FBS] [PAA, Austria]). PBMC with viability higher than $90 \%$ was subjected to the following assays.

\section{T cell and NK cell immunophenotyping for human PBMC}

The $\mathrm{T}$ cell and NK population in the control and extract treated PBMC were identified using flow cytometry surface antigen immunophenotyping. In brief, PBMC $\left(5 \times 10^{5}\right.$ cells/ $\mathrm{mL}$ ) was exposed to various concentrations of $R$. korthalsii methanol extract ( $50 \mu \mathrm{g} / \mathrm{mL}, 25 \mu \mathrm{g} / \mathrm{mL}$ or $1 \mu \mathrm{g} / \mathrm{mL}$ ) for 24 , 48 and 72 hours. Con-A $(1 \mu \mathrm{g} / \mathrm{mL})$ and LPS $(1 \mu \mathrm{g} / \mathrm{mL})$ treated PBMC and untreated PBMC were used as positive and negative controls respectively. All samples were then washed, double stained with $10 \mu \mathrm{g} / 10 \mu \mathrm{L}$ of conjugated anti-CD3 FITC (isotype control: Mouse IgG2a k) and $12.5 \mu \mathrm{g} / 10 \mu \mathrm{L}$ of conjugated anti-CD56 PE antibodies (isotype control: Mouse IgG1 k) and the population of $\mathrm{CD}^{+} \mathrm{T}$ cell and $\mathrm{CD}^{+} 6^{+} \mathrm{NK}$ cell were analyzed using BD FACSCalibur ${ }^{\text {ma }}$ flow cytometer with BD CellQuest ${ }^{\text {tm }}$ software (BD Biosciences, USA).

\section{NK cell Granzyme B and perforin expressions}

PBMC was treated with $R$. korthalsii extract at $25 \mu \mathrm{g} / \mathrm{mL}$ or rhIL-2 at $200 \mathrm{U} / \mathrm{mL}$ for 72 hours in 6 well plate (BD Biosciences, USA). 2 hours before the end of the incubation period, the production of perforin and granzyme $\mathrm{B}$ were inhibited by adding and mixing with $2 \mu \mathrm{L}$ of BD GolgiStop ${ }^{\mathrm{m}}$ into each experimental well. Then, $1 \times 10^{6}$ cells were harvested, washed with $1 \mathrm{~mL}$ of PBS and stained with 12.5 $\mu \mathrm{g} / 10 \mu \mathrm{L}$ of conjugated anti-CD 56-PE antibody in a final volume of $100 \mu \mathrm{L}$ PBS for 30 minutes at $4^{\circ} \mathrm{C}$. After that, the cells were washed and incubated with $250 \mu \mathrm{L}$ of Fixation/ Permeabilization solution (BD Biosciences, USA) for $20 \mathrm{mi}-$ nutes at $4^{\circ} \mathrm{C}$. Subsequently, the cells were then washed twice with BD Perm/Wash ${ }^{\mathrm{nx}}$ buffer, incubated with $5 \mu \mathrm{L}$ of either $10 \mu \mathrm{g} / 10 \mu \mathrm{L}$ of mouse anti-human Granzyme BFITC (Isotype control: Mouse IgG1, k) (BD Biosciences, USA) or $10 \mu \mathrm{g} / 10 \mu \mathrm{L}$ of mouse anti-human Perforin-FITC antibody (Isotype control: Mouse IgG2b, k) (BD Biosciences, USA), stained with second antibodies and analyzed using BD FACSCalibur ${ }^{\text {rm }}$ flow cytometer with BD CellQuest $^{\text {tw }}$ software (BD Biosciences, USA).

\section{NK cell Isolation}

The PBMC was subjected to activation and treatment as stated below and summarised in Figure 1. 


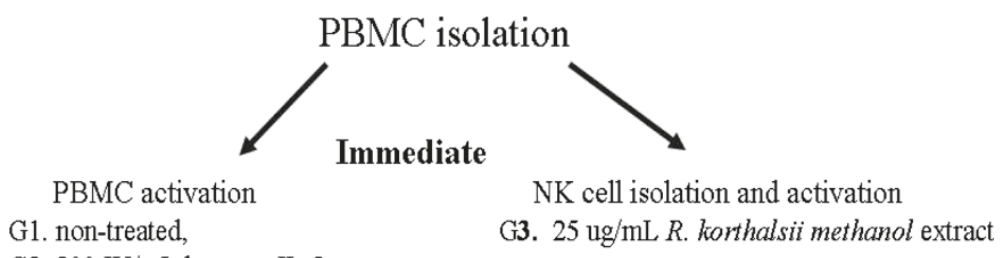

G2. $200 \mathrm{IU} / \mathrm{mL}$ human rIL-2,

G4. $25 \mathrm{ug} / \mathrm{mL}$ R. korthalsii methanol extract

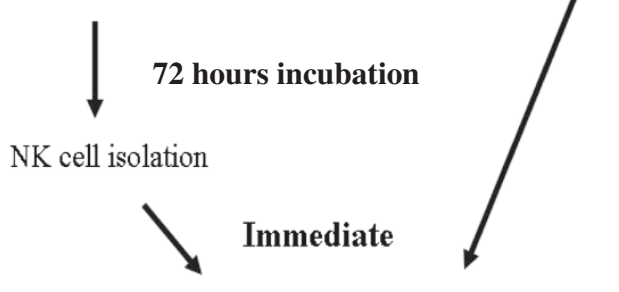

Bioassay

Figure 1 Brief description of NK cells treatment. G1 to G4 are the groups of treatment. Direct and indirect activations of $R$. korthalsii against NK cells were studied through isolation of NK cells before and after 72-hour incubation with the extract.

Group 1: non-treated PBMC was cultured for 72 hours and subjected to NK cell magnetic isolation

Group 2: PBMC was treated with $200 \mathrm{IU} / \mathrm{mL}$ of human rIL-2 treated for 72 hours before subjected to NK cell isolation

Group 3: Direct NK cells activation whereby freshly isolated PBMC was subjected to NK cell isolation and was further cultured in $25 \mu \mathrm{g} / \mathrm{mL}$ of $R$. korthalsii methanol extract for 72 hours.

Group 4: Indirect NK cell activation whereby PBMC was treated with $25 \mu \mathrm{g} / \mathrm{mL}$ of $R$. korthalsii methanol extract for 72 hours before subjected to NK cell magnetic isolation.

NK cell isolation kit by immunomagnetic negative selection (Milteny Biotech, Germany) was used to isolate primary NK cells from isolated PBMC. In brief, either the freshly isolated PBMC (for direct $R$. korthalsii methanol extract treatment) or the PBMC cultured 3 days with different treatment was magnetically labeled with a cocktail of NK cell Biotin-Antibody Cocktail followed by NK cell MicroBead Cocktail. The magnetically labeled cells were then separated using MS column in the magnetic field of the MACS separator. Purity of NK cells was quantified by using flow cytometry where the entire isolated NK cell was labeled with anti-CD16-FITC (isotype control: Mouse IgG1 K), anti-CD-56-PE (isotype control: Mouse IgG1 к) and analyzed by flow cytometer (BD Biosciences, USA). Isolated NK cell with purity more than $95 \%$ were used for further studies.

\section{ELISA for determination of extra-cellular Granzyme B, IFN- $\gamma$ and TNF- $a$}

Expressions of Granzyme B, IFN- $\gamma$ and TNF- $\alpha$ were performed using Cytokine Enzyme Link Immunosorbent
Assay (ELISA) kit (Bender MedSystems, Austria). In brief, the extracted human NK cells after 72 hours of different treatments were cultured for another 24 hours without treatment. Another group of direct and indirect extract treated NK cells were treated with $15 \mu \mathrm{g} / \mathrm{mL}$ of MQ1$17 \mathrm{H} 12$ antibody (BD, USA) to neutralize the activity of IL-2 contributed mainly by the surrounding cell especially in the indirect extract treated NK cell. Similarly, CD3 T cells were isolated using CD3 $\mathrm{T}$ cell isolation kit by immunomagnetic positive selection based on the same grouping for the NK cell in Figure 1. The supernatant of these different control and treatment groups of $\mathrm{T}$ cell were subjected to ELISA determination of extra-cellular Granzyme B, IFN- $\gamma$ and TNF- $\alpha$ levels and compared their effects with the treatments on the NK cell. The supernatant from each group was collected, added into the pre-coated plate of the kit and incubated for 3 hours. After that, these samples were washed and immediately added with 3,3',5,5'"-tetramethylbenzidine (TMB) Peroxidase substrate followed by $1 \mathrm{M}$ Phosphoric acid stop solution. The ELISA plate was read at absorbance OD of 450 and $620 \mathrm{~nm}$ wavelengths using a $\mu$ Quant ELISA Reader (Bio-Tek Instruments, USA). The results were expressed in $\mathrm{pg} / \mathrm{mL}$. Each experimental and control sample was assayed in three biological replicates. Data were expressed as $\mathrm{pg} / \mathrm{mL}$.

\section{In vitro cytotoxicity of NK cell on NK cell sensitive K562 cell line}

The cytotoxicity of effector NK cell towards target K562 cell in the ratio of $2: 1$ and 10:1 for 24 hours was determined using CytoTox 96 nonradioactive cytotoxicity assay kit (Promega, USA) according to the manufacturer's protocol. The percentage of cytotoxicity was calculated using the formula below 
$\%$ Cytotoxicity $=\frac{\text { OD sample }- \text { OD target spontaneous }- \text { OD effector spontaneous }}{\text { OD target spontaneous }- \text { OD effector spontaneous }} \times 100$

\section{Statistical analysis}

All tests were carried out with 3 independent experiments and each of the experiment consisted of 3 technical replicates. All results are expressed as Mean \pm Standard Error (S.E.M.). Significant levels $(\mathrm{p}<0.05)$ were evaluated using ANOVA test (one way) followed by post hoc Duncan test.

\section{Results}

R. korthalsii methanol extract increased the PBMC NK cell population

The changes of $\mathrm{CD}^{+} \mathrm{T}$ cell and $\mathrm{CD}^{+} 6^{+} \mathrm{NK}$ cell composition in PBMC after treated with $R$. korthalsii methanol extract were analyzed using flow cytometry. Based on the results in Table 1, human PBMC incubated with $25 \mu \mathrm{g} / \mathrm{mL}$ of extract led to a decreased number of the $\mathrm{T}$ cell population $\left(\mathrm{CD}^{+} \mathrm{CD} 56^{-}\right)$by 1.13 times but significantly $(P<0.05)$ increased the NK cell $\left(\mathrm{CD}^{-} \mathrm{CD}^{-} 6^{+}\right)$ population by 1.5 times. On the other hand, $50 \mu \mathrm{g} / \mathrm{mL}$ of extract stimulated the NK cell population while maintaining the $\mathrm{T}$ cell population which contributed to less significant changes of the NK cell $\left(\mathrm{CD}^{-} \mathrm{CD}^{-} 6^{+}\right)$ population as compared to $25 \mu \mathrm{g} / \mathrm{mL}$ of extract. Thus, $25 \mu \mathrm{g} / \mathrm{mL}$ of extract stimulated proliferation of NK cell rather than $\mathrm{T}$ cell in the PBMC.

\section{R. korthalsii methanol extract enhanced NK cell perforin and granzyme B expressions}

Since R. korthalsii methanol extract activated PBMC showed significantly higher level of NK cell numbers, NK cell endocytosis production of the apoptosis or

Table $1 \mathrm{~T}$ cell and NK cell immunophenotyping on human PBMC after treating with various concentrations of $\boldsymbol{R}$. korthalsii methanol extract or positive controls for $\mathbf{7 2}$ hours

\begin{tabular}{|c|c|c|}
\hline & \multicolumn{2}{|c|}{ T cell or NK cell population (\%) } \\
\hline & ${\mathrm{CD} 3^{+} \mathrm{CD}^{-} 6^{-}}^{-1}$ & $\mathrm{CD}^{-} \mathrm{CD}^{2} 6^{+}$ \\
\hline Control & $55.8 \pm 1.3^{x}$ & $9.6 \pm 2.7^{a}$ \\
\hline R. korthalsii $(50 \mu \mathrm{g} / \mathrm{mL})$ & $52.1 \pm 2.7^{x}$ & $12.1 \pm 1.3^{\mathrm{a}, \mathrm{b}}$ \\
\hline R. korthalsii $(25 \mu \mathrm{g} / \mathrm{mL})$ & $49.0 \pm 1.6^{y}$ & $17.5 \pm 3 .^{b}$ \\
\hline R. korthalsii $(1 \mu \mathrm{g} / \mathrm{mL})$ & $54.3 \pm 1.9^{x}$ & $8.9 \pm 1.2^{\mathrm{a}}$ \\
\hline rhlL-2 (200 IU/mL) & $56.2 \pm 2.5^{x}$ & $14.1 \pm 1.7^{\mathrm{b}}$ \\
\hline Con-A $(1 \mu \mathrm{g} / \mathrm{ml})$ & $61.0 \pm 2.4^{z}$ & $6.7 \pm 1.4^{c}$ \\
\hline LPS $(1 \mu \mathrm{g} / \mathrm{ml})$ & $47.9 \pm 1.1^{y}$ & $7.8 \pm 1.9^{\mathrm{a}, \mathrm{c}}$ \\
\hline
\end{tabular}

Values ( $n=9 ; 3$ independent experiments with three technical replicates each) represent the means \pm S.E.M. $x, y$ and $z$ indicate significant different among the groups for $\mathrm{CD} 3^{+} \mathrm{CD} 56^{-}$( $\mathrm{T}$ lymphocyte) while $\mathrm{a}, \mathrm{b}$ and $\mathrm{c}$ indicate significant different among the groups for $\mathrm{CD} 3^{-} \mathrm{CD} 56^{+}$(NK cell) $(\mathrm{P}<0.05)$. necrosis inducing proteins (Granzyme B and Perforin) in PBMC were quantified to explore the contribution of NK cells in PBMC cytotoxicity. As shown in Figure 2 and Figure 3, the rIL-2 and extract treated PBMC showed a significantly higher level of perforin or granzyme B co-expressing $\mathrm{CD}^{+} 6^{+}$cells $(13.52 \pm 1.16 \%$ and $13.82 \pm 2.33 \%$ for rIL-2 treated PBMC; $15.72 \pm 2.72 \%$ and $15.10 \pm 2.73 \%$ for extract treated PBMC). The frequencies of perforin ${ }^{+} / \mathrm{CD} 56^{-}$and Granzyme $\mathrm{B}^{+} / \mathrm{CD}$ $56^{-}$populations were only upregulated by the extract treated PBMC but not significant by rhIL-2 treated PBMC (Figures 2 and 3). From these results, both rIL-2 and extract were able to stimulate higher percentage of NK cell population with majority of $\mathrm{CD}^{+} 6^{+}$(> $75 \%$ ) co-expressed perforin and granzyme $\mathrm{B}$ as compared to control ( $\sim 61 \%$ for perforin and $\sim 51 \%$ for granzyme B) (This was calculated based on the $\mathrm{CD} 56^{+}$Perforin or Granzyme $\mathrm{B}^{+}$population divided by Total $\mathrm{CD}^{+} 6^{+}$ population from Figures 2 and 3).

\section{R. korthalsii methanol extract enhanced CD56 ${ }^{\text {bright }} \mathrm{CD} 16^{\text {dim }}$ NK cell population}

At least $95 \%$ of the isolated cells was $\mathrm{CD}^{+} 6^{+}$as shown in the upper and lower right columns of Figure 4. Treatments with rIL-2 and $R$. korthalsii extract were able to increase CD56 ${ }^{\text {bright }} \mathrm{CD} 16^{\text {dim }}$ NK cell population.

\section{R. korthalsii favored NK cell IFN- $\gamma$ and TNF-a secretion}

Together with the induction of intracellular perforin and granzyme B expressions, $R$. korthalsii methanol extract was also able to stimulate extracellular IFN- $\gamma$ and TNF- $\alpha$ production either by direct or indirect stimulation of the NK cells. When NK cells were cultured with 72 hours of extract, the expression of IFN- $\gamma$ and TNF- $\alpha$ were increased markedly as compared to the untreated control group or even with the human rIL-2 treated group whereas the secretion of granzyme $B$ was not affected (Table 2). The direct extract activated NK cells showed a lower level of IFN- $\gamma$ and TNF- $\alpha$ production as compared to indirect activated NK cells. This might be contributed by the uptake of cytokine (e.g. IL-2) produced by the neighbouring lymphocytes which were also stimulated by the extract in the same time. Thus, the level of IFN- $\gamma$ and TNF- $\alpha$ production were found to be the highest in the indirect extract treated NK cells followed by the direct extract treated NK cells and human rIL-2 treated NK cells. These results were supported by the reduction of IFN- $\gamma$ and TNF- $\alpha$ secretions in the indirect extract treated NK 




Figure 2 CD 56 and Perforin expression of (A) isotype control (B) untreated, (C) rhlL-2 treated or (D) R. korthalsii methanol extract treated PBMC. Values ( $n=9 ; 3$ independent experiments with 3 technical replicates each) represent the means \pm S.E.M. ${ }^{*}$ Significant $(P<0.05)$.

cells to comparable level as the direct extract treated NK cells with the presence of IL-2 neutralizing antibody MQ1-17H12 (BD, USA).

\section{R. korthalsii enhanced NK cell cytotoxicity}

The exposure of human natural killer cell to R. korthalsii extract directly or indirectly were associated with the activation of NK cell activity against the targeted cancer cell. A standard LDH microcytotoxicity assay was subsequently performed to quantify the cytotoxicity of the treated and non-treated NK cells against NK cell sensitive K562 cell line. Figure 5 showed that LDH was released in the culture medium following a 24 hours of treated or non-treated NK cell exposures towards K562 cell at the ratio of 2:1 and 10:1. Two-hour-exposure of K562 cells with NK cells treated directly or indirectly with $25 \mu \mathrm{g} / \mathrm{mL}$ of $R$. korthalsii methanol extract raised $\mathrm{LDH}$ leakage to $42 \pm 1.7 \%$ and $58 \pm 4.1 \%$ respectively. The cytotoxicity was further increased when the number of NK cells increased from 2 times to 10 times against the total cell number of K562. All of the treated NK cells showed better cytotoxicity against K562 cells as compared to untreated NK cells with the differential sensitivities of the treatments in the following order: $R$. korthalsii indirect activated NK cells $>$ rhIL-2 indirect treated NK cells $>R$. korthalsii direct activated NK cells $>$ untreated NK cells.

\section{Discussion}

An immunomodulator is a compound or substance that is capable of either up-regulating or down-regulating a specific aspect of the host immune system. IL-2 has been identified as the NK cell immunomodulator in tumor immunotherapy. However, low concentration of IL-2 was failed to induce adequate amount of immune cell cytotoxicity towards tumor regression while high concentration of IL-2 can produce a severe lymophopenia and toxic side effect $[13,14]$. Thus, searching for novel immunomodulator which can work synergistically with IL-2 to reduce or replace its working dosage has been proposed from time to time and this may contribute to the success of adoptive immunotherapy in cancer treatment. Previously, the in vitro and in vivo proliferation and cytokine secretion studies have showed that $R$. korthalsii methanol extract has no suppressive effect but on the other hand has stimulation effect on mice and human lymphocyte function [8-11]. In this study, $R$. korthalsii methanol extract had stimulated NK cell population in a dosage dependent manner (Table 1). Low concentration of extract $(1 \mu \mathrm{g} / \mathrm{mL})$ did not alter significant changes $(\mathrm{p}<0.05)$ on both $\mathrm{T}$ and NK cell population. However, $25 \mu \mathrm{g} / \mathrm{mL}$ specifically promoted the increased of NK cell population which associated with slight reduction of $\mathrm{T}$ cell population. High concentration of extract possessed similar effect as rIL-2 where the increased 


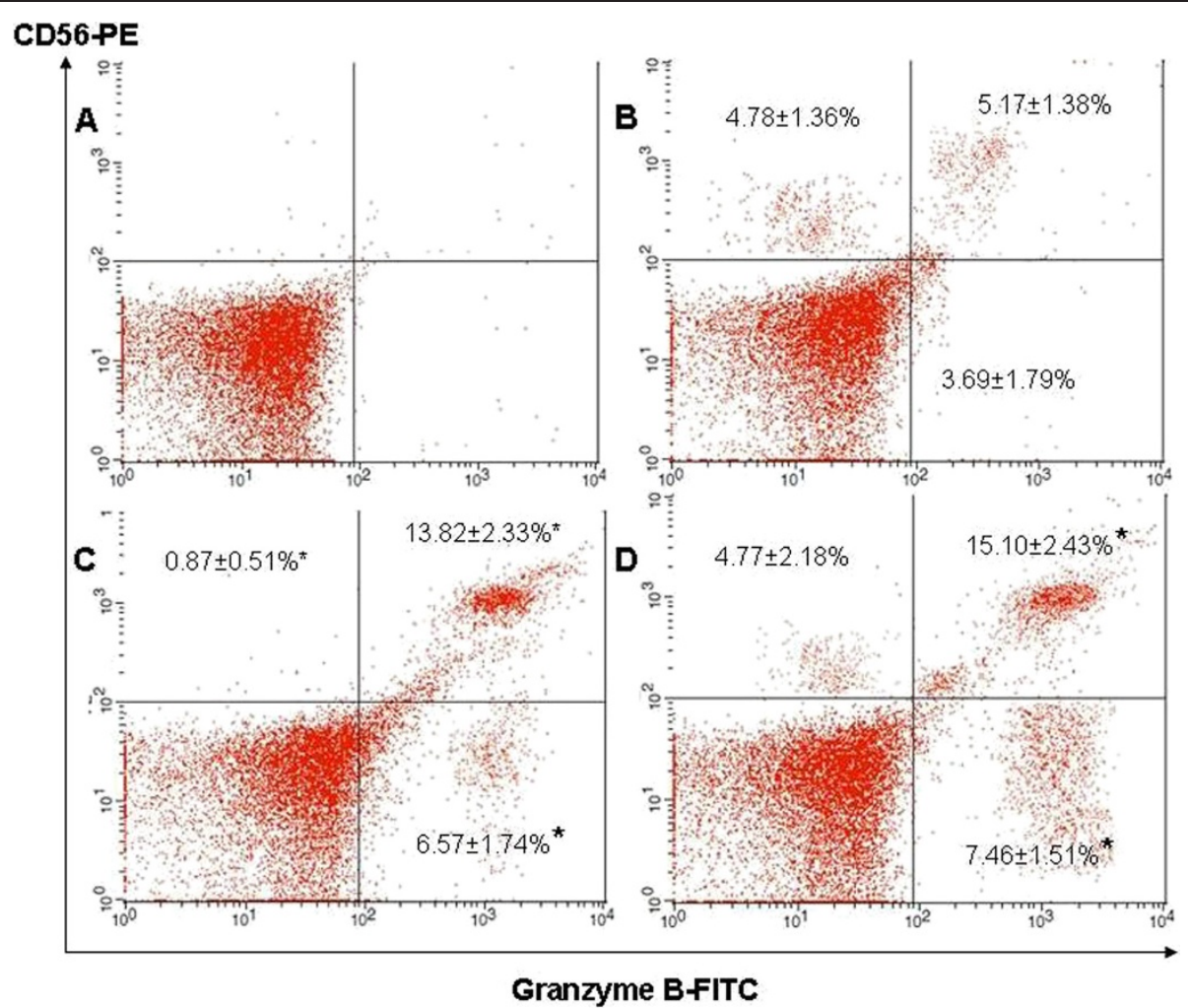

Figure 3 CD 56 and Granzyme B expression of (A) isotype control (B) untreated, (C) rhIL-2 treated or (D) R. korthalsii methanol extract treated PBMC. Values $\left(n=9 ; 3\right.$ independent experiments with 3 technical replicates each) represent the means \pm S.E.M. ${ }^{*}$ Significant $(P<0.05)$.

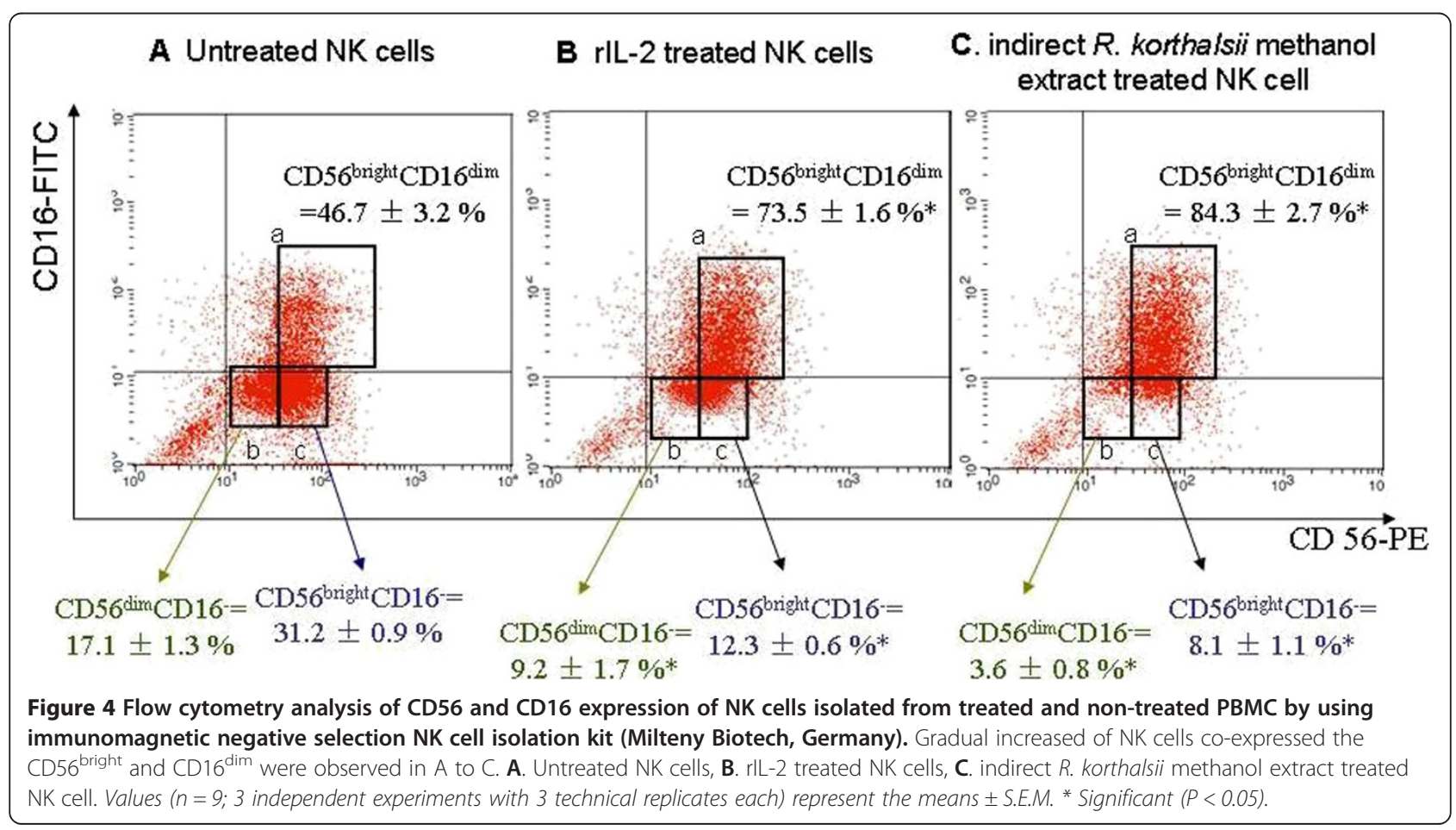


Table 2 ELISA Granzyme B, TNF-a and IFN-ץ detection of untreated, human rIL-2 treated, direct or indirect $R$. korthalsii methanol extract stimulated Human NK cells

\begin{tabular}{|c|c|c|c|}
\hline & Granzyme B & $\begin{array}{l}\text { TNF-a } \\
\text { (pg/mL) }\end{array}$ & IFN- $\gamma$ \\
\hline \multicolumn{4}{|l|}{ CD56 NK cell } \\
\hline Untreated NK cells & $72.3 \pm 9.5^{i}$ & $89.1 \pm 11.3^{x}$ & $857.5 \pm 19.5^{\mathrm{a}}$ \\
\hline Human rlL-2 treated NK cells & $86.2 \pm 4.1^{\mathrm{i}}$ & $743.3 \pm 15.6^{y}$ & $3672.6 \pm 28.1^{b}$ \\
\hline Direct $R$. korthalsii extract treated NK cells & $79.1 \pm 8.5^{i}$ & $478.9 \pm 17.8^{z}$ & $2954.2 \pm 27.9^{c}$ \\
\hline Indirect $R$. korthalsii extract treated NK cells & $88.5 \pm 7.3^{i}$ & $814.1 \pm 21.3^{2 z}$ & $6238.8 \pm 38.2^{d}$ \\
\hline Direct $R$. korthalsii extract treated NK cells $+\mathrm{MQ1-17H12}$ antibody & $78.4 \pm 5.7^{i}$ & $442.9 \pm 26.5^{z}$ & $2713.9 \pm 33.5^{c}$ \\
\hline Indirect $R$. korthalsii extract treated NK cells + MQ1-17H12 antibody & $83.6 \pm 6.2^{i}$ & $527.4 \pm 31.3^{z}$ & $3112.2 \pm 41.7^{c}$ \\
\hline \multicolumn{4}{|l|}{ CD3 T cell } \\
\hline Untreated CD3 T cells & $66.4 \pm 4.7^{i}$ & $84.5 \pm 9.3^{x}$ & $691.2 \pm 28.5^{\mathrm{e}}$ \\
\hline Human rIL-2 treated CD3 T cells & $69.8 \pm 5.2^{i}$ & $876 \pm 24.7^{77}$ & $2976 \pm 36.1^{c}$ \\
\hline Direct $R$. korthalsii extract treated CD3 T cells & $65.3 \pm 7.1^{i}$ & $215.8 \pm 41.2^{27 z}$ & $977.2 \pm 28.4^{f}$ \\
\hline Indirect $R$. korthalsii extract treated CD3 T cells & $68.2 \pm 8.3^{i}$ & $164.5 \pm 33.9^{z 7 z}$ & $756.3 \pm 23.9^{e}$ \\
\hline
\end{tabular}

Values ( $n=9 ; 3$ independent experiments with three technical replicates each) represent the means \pm S.E.M. Significant $(P<0.05)$. i indicate no significant different among the groups for Granzyme B; $x, y, z, z z, z z z$ indicate significant different among the groups for TNF-a while a, b, c. d. e and f indicate significant different among the groups for IFN- $\gamma(\mathrm{P}<0.05)$.

of NK cell population was associated with the maintenance of high population of $\mathrm{T}$ cell. This phenomenon has suggested that high concentration of $R$. korthalsii methanol extract can work similarly as rIL-2 to stimulate both population of $\mathrm{T}$ and NK cell [15] while $25 \mu \mathrm{g} / \mathrm{mL}$ of extract selectively stimulated NK cell more than T cell.

In this study, our results showed that extract enhanced the production of perforin and granzyme B on both $\mathrm{CD} 56^{+}$ and $\mathrm{CD}^{-}$populations in PBMC (Figures 2 and 3). Thus, up-regulation of PBMC cytotoxicity against tumor target hepatoblastoma HepG2 cell and erythroleukemia K562 cell line [9-11] may be contributed by either the NK $\left(\mathrm{CD} 56^{+}\right)$ or non-NK (cytolytic $\mathrm{T}$ which is $\mathrm{CD} 56^{-}$) killer cells. Previously, Wahlberg et al. [16] showed that NK cells were the sole effector cells actively involved in killing the tumor cell target as compared to other potential cytotoxic immune effector cells such as Tumor-specific cytotoxic T lymphocytes and cytotoxic NK-T cells. K562 cells are tumor target cells which are sensitive to NK cell cytolytic activity. Thus, the reduction of the $\mathrm{K} 562$ cells' viability might be contributed by the NK cell cytolytic activity which was further upregulated by the $R$. korthalsii methanol

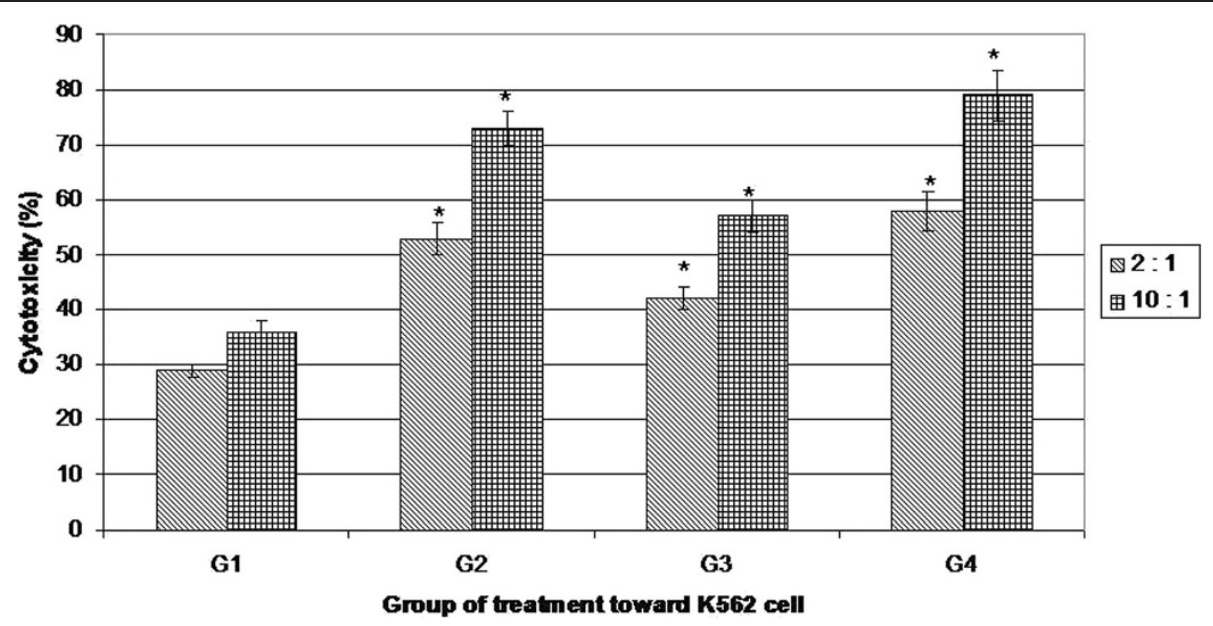

Figure 5 Cytotoxicity of treated or non-treated NK cells towards K562 cell at ratio of effector NK cell to target K562 cell at 2:1 and 10:1 evaluated by LDH microcytotoxicity assay. G1 is untreated NK cells; G2 is Human rlL-2 treated NK cells; G3 is direct R. korthalsii extract treated NK cells; G4 is indirect R. korthalsii extract treated NK cells. Each value represents the means \pm S.E.M. for 3 independent experiments with 3 technical replicates each. The differences between the control group and treated group were determined by one-way ANOVA (*P $<0.05)$. 
extract. NK cells are large granular lymphocytes in the innate immunity which kill the tumor or virus infected target cells by using three mechanisms [17]. The first mechanism is by secreting granules which contain perforin and granzymes that induce necrosis and apoptosis respectively. Perforin is a killer-cell specific cytolytic mediator produced by cytotoxic lymphocytes and stored in cytoplasmic granules. Both perforin and granzyme are originated from cytolytic serine-proteinases family and work synergistically to lyse the cell targeted by cytolytic lymphocytes such as cytolytic T and NK cells. These proteins were reported previously to be present in the rIL-2 induced PBMC and were degranulated towards the target cells during cell mediated cytotoxicity [18]. IL-2 was previously found to be secreted upon extract activation [11] at a lower concentration as compared to the rIL-2 which was used as the control in this study. Thus, it is possible that up-regulation of perforin and granzyme B production in the NK cells maybe stimulated via both extract or IL-2 produced by extract stimulated lymphocytes. The second mechanism is by TNF receptor family ligand interaction such as Fas ligand (Fas L)/Fas pathway [19] and the third would be the secretion of antitumor cytokine such as IFN- $\gamma$. Previous study showed that HepG2 was resistant towards the TNF family Fas L/Fas induced apoptosis pathway of NK cell but sensitive to NK cell granule dependent necrotic death [20]. It was found that 72 hours of extract activation also induced high production of extra-cellular $\mathrm{T}$ helper 1 cytokine, IFN- $\gamma$ [11]. The question to this phenomenon was which population of cells in PBMC was contributed to the up-regulation of IFN- $\gamma$ secretion upon extract stimulation. The immunophenotyping of PBMC postulated that high expression of IFN- $\gamma$ may be contributed by NK cell population rather than $\mathrm{T}$ cell. This was because at that specific concentration, $R$. korthalsii methanol extract had up-regulated the NK cell population while reduced the T cell population in the CD3 and CD56 immunophenotyping of the extract treated or none treated PBMC (Table 1). Modulation on IFN- $\gamma$ production has previously reported to affect NK cell cytotoxicity [21]. Thus, enhancement of immune cell cytolytic activity may be contributed by the synergistic effect of both cytolytic proteins (granzyme B and perforin) and also antitumor cytokine (IFN- $\gamma$ ). Although the exact mechanism of $R$. korthalsii methanol extract in activating immune cell cytotoxicity is yet to be fully understood, it is expected that the activation may be due to the direct binding effect of the extract to NK cells or indirect effect of IL-2 secreted by accessory cells in PBMC. To confirm the activation of extract on NK cell, CD56 enriched NK cell population was isolated from $\mathrm{PBMC}$ and subjected to investigation of perforin, granzyme $\mathrm{B}$ and cytokine expressions.
Different treatment groups were setup in order to elucidate the mechanisms of cytotoxicity activity and NK cell activation by $R$. korthlasii methanol extract. We have previously showed that extract-treated PBMC secreted higher level of IL-2 production as compared to the nontreated cells. This result gave an insight that the extract may not only activate NK cells but also other types of immune cells in the PBMC culture. Moreover, CD4 T cell and NK cells were found to work synergistically towards tumor removal [22]. Thus, in this study, the treated and non-treated PBMC were cultured for 72 hours prior to NK cell isolation to allow cell-to-cell interactions for better cytotoxic effect towards tumor cells. On the other hand, NK cells which express $\mathrm{CD} 56^{+} \mathrm{CD} 16^{-/+}$were also isolated from fresh PBMC (Figure 1) before treated with $R$. korthalsii methanol extract for a better understanding of the immunoregulatory effect contributed by direct interaction between the extract and NK cells. NK cells directly isolated from fresh blood for direct extract activation shared similar 1:1 ratio of $\mathrm{CD} 16^{+}$ and $\mathrm{CD} 16^{-}$population as in the non-treated PBMC isolated NK cells (Figure 4). As compared to untreated PBMC, NK cells isolated from the rIL-2 or extract treated PBMC showed an increment of $\mathrm{CD} 56^{\text {bright }} \mathrm{CD} 16^{\text {dim }}$ population. CD56 $6^{\text {bright }} \mathrm{CD} 16^{\text {dim }}$ NK cell population plays an important role to produce cytokines such as IFN- $\gamma$ and only possess weak cytotoxicity against tumor [23]. The increment of this population (Figure 4) after stimulated by rIL-2 and $R$. korthalsii methanol extract had strong correlation with higher production (Table 2).

Our previous studies have demonstrated that $R$. korthalsii methanol extract could enhance immune cells proliferation, Th1 cytokine expression and cytotoxicity. In this study, apart from the direct activation of the $R$. korthalsii methanol extract on the NK cells isolated from fresh human blood, the effect of the extract on NK cells was also monitored through isolation of NK cells from the pre-activated PBMC. This approach of activation was chosen because immune cells activation involves a signaling cascade from innate immunity to adaptive immunity which includes multiple types of immune cells. For example, a change in dendritic cells self-markers can trigger NK cells activation which further promotes the activation of dendritic cells and lead to the priming of Th1 responses [24]. From the results obtained, $R$. korthalsii methanol extract had demonstrated both direct and indirect immunoregulatory effect on human NK cell cytotoxicity in vitro.

Although $\mathrm{CD}^{\text {bright }} \mathrm{CD} 16^{\mathrm{dim}}$ NK cell population possessed less cytotoxicity against tumor as compared to CD56 ${ }^{\text {dim }}$ NK cell, the present of cytokines especially IL-2 can significantly improved the cytotoxicity of all subtypes of NK cell [23]. Thus, isolated NK cell 
treated with rIL-2 and extract were observed to have higher cytotoxicity against K562 cell. Besides, the way NK cells counter react with tumor involved not only the NK cells' cytolytic activity but also those of the other cytokines. Krishnaraj and Bhooma [25] found that senescent NK cells showed cytokine secretory deficiency which contributed to tumor establishment and viral infection although NK cell cytotoxicity remained the same. In this study, the enhancement of IFN- $\gamma$ and TNF- $\alpha$ production by the extract activated NK cells was confirmed by ELISA. The results showed that the level of IFN- $\gamma$ expression by pure NK cell population from either extract direct or indirect activation were quite similar to the level of IFN- $\gamma$ expressed by extract activated PBMC in our previous report [11]. Furthermore, IFN- $\gamma$ and TNF- $\alpha$ productions in extract treated isolated CD3 T cell were much lower as compared to NK cell. This result gave the idea that IFN- $\gamma$ produced by extract activated PBMC was contributed mainly by the extract direct or indirect activated NK cells and this results was supported by the IL-2 neutralizing groups where addition of MQ1-17H12 antibody only affected the secretion of IFN- $\gamma$ and TNF- $\alpha$ for the indirect extract treated NK cell. IFN- $\gamma$ is a multifunctional cytokine with wide stimulatory effects on anti-tumoral immune reactions either through direct cytotoxic effect on tumor cells or indirect stimulation of immune effector cells such as macrophages and NK cells to target on the tumor. IFN- $\gamma$ mediates NK cells' cytolytic activity through the increase of the ULBP level of the tumors cells which then binds to the NKG2D [26]. Binding of RAET1G3 which is the variant of ULBPs expressed by HepG2 was found to stimulate NK cells to further enhance IFN- $\gamma$ secretion [27]. This idea had raised the possibility that IFN- $\gamma$ production stimulated by $R$. korthasii methanol extract might contribute to the activation of NK cells' cytotoxicity against HepG2 and K562 [9-11]. Enhancement of the NK cell cytolytic activity toward K562 cell by the extract was confirmed in this study. However, IFN- $\gamma$ by itself did not demonstrate a sufficient amount of cytotoxicity to kill the tumor cells. Aid from other cytokines such as TNF- $\alpha$ could have overcome this barrier [28]. Thus, IFN- $\gamma$, TNF- $\alpha$, granzyme $B$ and perforin stimulation may contribute to a higher level of NK cells' cytotoxicity towards K562 cells as compared to the untreated NK cells. All of the above results showed strong evidence that activation of $R$. korthalsii methanol extract contributes to the enhancement of NK cell cytotoxicity. In this study, no significant amount of granzyme B was detected in the supernatant of the culture. This result carried the message that spontaneous leakage of granzyme B did not take place in all of the untreated and treated NK cells. Leakage of Granzyme B into cytosol and extracellular environment was found to induce NK cell self-apoptosis, which is termed "Granzyme B leakage-induced cell death" (GLCD) [29]. Thus, GLCD did not occur in all of the untreated or treated NK cells in this experiment as no significant leakage of Granzyme B was detected.

\section{Conclusion}

Our study gave strong indication that synergistic effects of $R$. korthalsii methanol extract and IL-2 expressed by the neighouring cells in the PBMC population produced a greater net activation over NK cells. NK cells isolated from the PBMC treated with $R$. korthalsii methanol extract resulted in a higher expressions of perforin, granzyme $B$, IFN- $\gamma$, TNF- $\alpha$, in comparison to those that were treated with rIL-2 alone or PBMC isolated NK cell directly treated with the extract. This finding suggested the potential future use of $R$. korthalsii methanol extract as an alternative to mono-immunotherapy by IL- 2 in adoptive immunotherapy. Future studies should focus on the isolation of the active compounds present in $R$. korthalsii and the evaluation of the effects of these compounds on activation and inhibition markers of NK cell.

\section{Competing interests}

The authors declare that they have no competing interests.

\section{Authors' contributions}

SKY conceived the study, carried out the experimentation, acquisition and analysis of data and drafting of the manuscript. WYH and BKB assisted with the concept, analysis of data and drafting of the manuscript. AMA and NBA provided funding. ARO, AMA and NBA conceived, designed and supervised the study and revised the manuscript. All authors have read and approved the final manuscript

\section{Acknowledgements}

The authors would like to thank Universiti Putra Malaysia for funding the project under the RUGS grant 91801. The authors would also like to thank Professor Tan Soon Guan for proof reading.

\section{Author details}

${ }^{1}$ Institute of Bioscience, University Putra Malaysia, Serdang, Selangor, Malaysia. ${ }^{2}$ Department of Veterinary Pathology and Microbiology, Faculty of Veterinary Medicine, University Putra Malaysia, Serdang, Selangor, Malaysia. ${ }^{3}$ Department of Cell and Molecular Biology, Faculty of Biotechnology and Biomolecular Sciences, University Putra Malaysia, 43400, Serdang, Selangor, Malaysia. ${ }^{4}$ Faculty of Agriculture and Biotechnology, University Sultan Zainal Abidin, Kampus Kota, Jalan Sultan Mahmud, Kuala Terengganu 20400, Malaysia. ${ }^{5}$ Department of Bioprocess Technology, Faculty of Biotechnology and Biomolecular Sciences, University Putra Malaysia, 43400, Serdang, Selangor, Malaysia.

Received: 26 August 2012 Accepted: 10 June 2013

Published: 24 June 2013

\section{References}

1. Wang Y, Wang W, Li N, Yu Y, Cao X: Activation of antigen-presenting cells by immunostimulatory plant DNA: a natural resource for potential adjuvant. Vaccine 2002, 20:2764-2771

2. Federica C, Cristina N, Anna C, Nunziatina DT, Antoonella L, Lucia M: In vitro binding studies of methanolic extracts from different Salvia species. Pharmacologyonline Young Researchers 2006, 1:1-10.

3. Darien BJ, Godbee RG: Morinda citrifolia based formulations for regulating T cell immunomodulation in neonatal stock animals. In US 2009/ 0068204A. Edited by MCCONKIE K a. US; 2009. 
4. Kumar RA, Sridevi K, Kumar NV, Nanduri S, Rajagopal S: Anticancer and immunostimulatory compounds from Andrographis paniculata. J Ethnopharmacol 2004, 92:291-295.

5. Kiritikar KR, Basu BD: Indian medical plant. pp. 3578-3622. Dehradum: Oriental Enterprises; 2001

6. Lau TT, Ong LB, Fang TH: The antioxidant potential and immunomodulating activity of dragon plant. 2004. Retrieve 31 May, 2010 from http://www. science.edu.sg/ssc/events.jsp?artid $=5705 \&$ type $=17 \&$ root $=268 \&$ parent $=268 \&$ cat $=330$.

7. Tan ML, Muhammad TST, Najimudin N, Sulaiman SF: Growth arrest and non-apoptotic programmed cell death associated with the up-regulation of c-myc mRNA expression in T-47D breast tumor cells following exposure to Epipremnum pinnatum (L.) Engl. hexane extract. J Ethnopharmacol 2005, 96:375-383.

8. Wong KT, Tan BKH: In vitro cytotoxicity and immunomodulating property of Rhaphidophora korthalsii. J Ethnopharmacol 1996, 52:53-57.

9. Yeap SK, Alitheen NB, Ali AM, Omar AR, Raha AR, Suraini AA, Muhajir AH: Effect of Rhaphidophora korthalsii methanol extract on human peripheral blood mononuclear cell proliferation and cytolytic activity toward HepG2. J Ethnopharmacol 2007, 114:406-411.

10. Yeap SK, Omar AR, Ali AM, Ho WY, Beh BK, Alitheen NB: Immunomodulatory effect of Rhaphidophora korthalsii on natural killer cell cytotoxicity. Evidence-Based Complementary and Alternative Medicine 2012, 2012:Aritcle ID 786487.

11. Yeap SK, Alitheen NBM, Ho WY, Omar AR, Ali AM, Beh BK, Yousr AHN Immunomodulatory role of Rhaphidophora korthalsii methanol extract on human peripheral blood mononuclear cell proliferation, cytokine secretion and cytolytic activity. Journal of Medicinal Plant Research. 2011, 5:958-965.

12. Gobel TWF, Kaspers B, Stangassinger M: NK and T cells constitute two major, functionally distinct intestinal epithelial lymphocyte subsets in the chicken. Int Immunol 2001, 13:757-762.

13. Ozdemir O, Savasan S: Combinational IL-2/IL-15 induction does not further enhance IL-15-induced lymphokine-activated killer cell cytotoxicity against human leukemia/lymphoma cells. Clin Immunol 2005, 115:240-249.

14. Porrata LF, Inwards DJ, Lacy MQ, Markovic SN: Immunomodulation of early engrafted natural killer cells with interleukin-2 and interferon-alpha in autologous stem cell transplantation. Bone Marrow Transplant 2001, 28:673-680.

15. Perussia B, Ramoni C, Anegon I, Cuturi MC, Faust J, Trinchieri G: Preferential proliferation of natural killer cells among peripheral blood mononuclear cells cocultured with B lymphoblastoid cell lines. Nat Immun Cell Growth Regul 1987, 6:171-188.

16. Wahlberg BJ, Burholt DR, Kornblith P, Richards TJ, Bruffsky A, Herberman RB, Vujanovic NL: Measurement of NK activity by the microcytotoxicity assay (MCA): a new application for an old assay. J Immunol Methods 2001, 253:69-81.

17. Li Q, Nakadai A, Ishizaki M, Morimoto K, Ueda A, Krensky AM, Kawada T: Dimethyl 2,2-dichlorovinyl phosphate (DDVP) markedly decreases the expression of perforin, granzyme A and granulysin in human NK-92C cell line. Toxicology 2005, 213:107-116.

18. Trapani JA, Klein JL, White PC, Dupont B: Molecular cloning of an inducible serine esterase gene from human cytotoxic lymphocytes. Proc Natl Acad Sci 1988, 85:6924-6928.

19. Li Q, Nakadai A, Takeda K, Kawada T: Dimethyl 2,2-dichlorovinyl phosphate (DDVP) markedly inhibits activities of natural killer cells, cytotoxic T lymphocytes and lymphokine-activated killer cells via the Fas-ligand/Fas pathway in perforin-knockout (PKO) mice. Toxicology 2004, 204:41-50.

20. Kim HR, Park HJ, Park J, Kim S, Kim K, Kim J: Characteristics of the killing mechanism of human natural killer cells against hepatocellular carcinoma cell lines HepG2 and Hep3B. Cancer Immunol Immunother 2004, 53:461-470.

21. Santarelli $L$, Bracci M, Mocchegiani $E$ : In vitro and in vivo effects of mercuric chloride on thymic endocrine activity, NK and NKT cell cytotoxicity, cytokine profiles (IL-2, IFN- $\gamma$, IL-6): Role of the nitric oxide-L -arginine pathway. Int Immunopharmacol 2006, 6:376-389.

22. Su L, Tian $H, X u Y$, , Geng $Y$ : NK activity of lymphocyte subsets and the effects of low dose radiation. Chinese Journal of Cancer Research 1998, 10:37-40.

23. Poli A, Michel T, Theresine M, Andres E, Hentges F, Zimmer J: CD56 ${ }^{\text {bright }}$ natural killer (NK) cells: an important NK cell subset. Immunology 2009 126:458-465.
24. Reis E, Sousa C: Activation of dendritic cells: translating innate into adaptive immunity. Curr Opin Immunol 2004, 16:21-25.

25. Krishnaraj R, Bhooma T: Cytokine sensitivity of human NK cells during immunosenescence. 2. IL2-induced Interferon gamma secretion. Immunol Lett 1996, 50:59-63.

26. Rohner A, Langenkamp U, Siegler U, Kalberer CP, Wodnar-Filipowicz A: Differentiation-promoting drugs up-regulate NKG2D ligand expression and enhance the susceptibility of acute myeloid leukemia cells to natural killer cell-mediated lysis. Leuk Res 2007, 31:1393-1402.

27. Cao W, Xi X, Wang Z, Dong L, Hao Z, Cui L, Ma C, He W: Four novel ULBP splice variants are ligands for human NKG2D. Int Immunol 2008, 20:981-991.

28. Rushfeldt C, Sveinbjornsson B, Seljelid R, Smedsrod B: Early events of hepatic metastasis formation in mice: Role of kupffer and NK-cells in natural and interferon- $\gamma$-stimulated defense. J Surg Res 1999, 82:209-215

29. Ida H, Utz PJ, Anderson P, Eguchi K: Granzyme B and natural killer (NK) cell death. Mod Rheumatol 2005, 15:315-322.

doi:10.1186/1472-6882-13-145

Cite this article as: Yeap et al:: Rhaphidophora korthalsii modulates peripheral blood natural killer cell proliferation, cytokine secretion and cytotoxicity. BMC Complementary and Alternative Medicine 2013 13:145.

\section{Submit your next manuscript to BioMed Central and take full advantage of:}

- Convenient online submission

- Thorough peer review

- No space constraints or color figure charges

- Immediate publication on acceptance

- Inclusion in PubMed, CAS, Scopus and Google Scholar

- Research which is freely available for redistribution

Submit your manuscript at www.biomedcentral.com/submit
C) Biomed Central 